\title{
ADDED NERINEOID GASTROPOD EVIDENCE FOR A WARM TURONIAN SEA IN SOUTHERN CALIFORNIA
}

\author{
L. R. SAUL AND R. L. SQUIRES \\ Natural History Museum of Los Angeles County, 900 Exposition Blvd., Los Angeles, CA 90007, <lousaul@earthlink.net>, and \\ Department of Geological Sciences, California State University, Northridge 91330-8266, <richard.squires@csun.edu>
}

\section{INTRODUCTION}

NERINEOIDS, so typical of the Jurassic and Early Cretaceous in Europe, are usually rare and lacking in diversity in North America north of Mexico. This is especially true of the Pacific slope faunas. Only three species of nerineoid gastropods have previously been reported from the Cretaceous of California (Saul and Squires, 1998). The oldest of these species, Aphanoptyxis andersoni Saul and Squires, 1998, is from the Early Cretaceous (Hauterivian) in northern California. The other two species are Late Cretaceous (Turonian): Aphanoptyxis californica Saul and Squires, 1998, is from northern California, and Nerinella santana Saul and Squires, 1998, is from a locality and strata in southern California near the occurrence of Nerinella califae $\mathrm{n}$. sp. The description of $N$. califae $\mathrm{n}$. sp. gives California the greatest diversity of Turonian northeastern Pacific slope nerineoids, namely, Aphanoptyxis californica and two species of Nerinella. These Turonian nerineoids are also, thus far, the geologically youngest North American Pacific slope nerineoids.

Aphanoptyxis californica was described from the Hornbrook Formation in Siskiyou County and the Redding Formation in Shasta County, northern California. This northern nerineoid is from east of the San Andreas Fault. Nerinella santana and $N$. califae, on the other hand, are from the Santa Ana Mountains, which are west of the San Andreas Fault. The Santa Ana Mountains have been moved relatively northward, and they are now several hundred kilometers nearer northern California than they were during the Cretaceous (Fry et al., 1985).

Nerineoids are commonly an important element of Mesozoic carbonate faunas and form part of the subtropical to tropical Tethyan-rudist-coral assemblages (Sohl, 1987; Barker, 1990). Limestones are rare in California Cretaceous deposits, and the two Californian Turonian species are from nearshore arenaceous sediments rather than carbonate deposits. These two species are not as yet known to be associated with rudists or corals, although a few specimens of both rudists and corals have been recovered from other localities of Turonian age in the Santa Ana Mountains. Also suggestive of subtropical to tropical conditions in the Turonian are occurrences of such Tethyan mollusks as the bivalve Trigonarca Conrad, 1862 and the gastropod Trochacteon Meek, 1863 , in nearshore strata into northern California (Sohl and Kollmann, 1985).

Both $N$. santana and $N$. califae $\mathrm{n}$. sp. are considered to be from the Baker Canyon Sandstone Member of the Ladd Formation and of Turonian age, based on sandstone lithologies of the matrix and on fossil content. The Baker Canyon Sandstone Member was mapped in the type area of $N$. califae n. sp. by Morton and Miller $(1973,1981)$ whose map indicates a landslide of Baker Canyon Sandstone Member strata in that vicinity. Relative stratigraphic positions of $N$. santana and $N$. califae n. sp. are unknown because of structural complications and the inadequately described stratigraphy within the Baker Canyon Sandstone Member. Additionally, data on the type locality for $N$. santana, LACMIP 8170, "Creek at road junction, Aliso Creek, Trabuco Oaks, Santa Ana Mountains," are imprecise and conflicting. Aliso Creek is 3 to $4 \mathrm{~km}$ northwest of Trabuco Oaks, which is near the confluence of Hickey and Trabuco Creeks (Fig. 1). Popenoe (personal commun.) said that C. R. Stauffer, the collector of locality LACMIP 8170, picked up fossiliferous boulders along a creek, presumably a southwesterly flowing creek, crossed by the road between Aliso Creek and Trabuco Oaks. Both species are locally abundant and come from north of Plano Trabuco at the southern end of the northern Santa Ana Mountains. Nerinella califae $\mathrm{n}$. $\mathrm{sp}$. is, however, from a much finer grained sandstone than is $N$. santana.

Deposits of both $N$. califae and $N$. santana were similar in that the specimens were closely aggregated in the sandstone, with little matrix between aligned specimens. Most, if not all, of the $N$. califae shells appear to have been broken before or during deposition but do not appear much worn by long abrasion. Shell hash is not noticeably present, as most fragments comprise several complete whorls and are of moderate length. All growth stages are represented, but no apertures were found. Unfortunately, further breakage occurred during extraction. The resultant fragments suggest that the height of $N$. califae was in excess of 36 times its diameter (for comparison, consider that in length an ordinary lead pencil is about 25 times its diameter and does not taper). At a maximum diameter of $11 \mathrm{~mm}, N$. califae probably exceeded 35 $\mathrm{cm}$ in height.

Possible nerineoid-feeding strategies range from epifaunal algal browsing, deposit feeding, suspension filter feeding, to predation (Barker, 1990). Taylor et al. (1980) suggested that nerineoids were infaunal deposit-feeders. Barker (1990) indicated that they were infaunal, based on the absence of epibionts, and he further suggested that they were probably herbivorous deposit feeders. There has been little definitive evidence to support a clear choice of nerineoid feeding mode, and, unfortunately, the Ladd Formation specimens have probably been moved by postmortem transport. Their abundance in the matrix is, however, somewhat more suggestive of a suspension filter feeder than of a predator. Epibionts were not noted on $N$. califae, but cleaning difficulties caused by the hard sandstone matrix would make recognition of them difficult.

The higher classification of nerineoids remains a subject of debate. The categories herein are those of Ponder and Warén (1988). Kowalke and Bandel (1996) claim heterstrophic protoconchs in two species of nerineoids, a finding that would support the classification of Ponder and Warén (1988).

Abbreviations used are CIT = California Institute of Technology (collections now at LACMIP), GSC = Geological Survey of Canada, and LACMIP = Natural History Museum of Los Angeles County, Invertebrate Paleontology. 


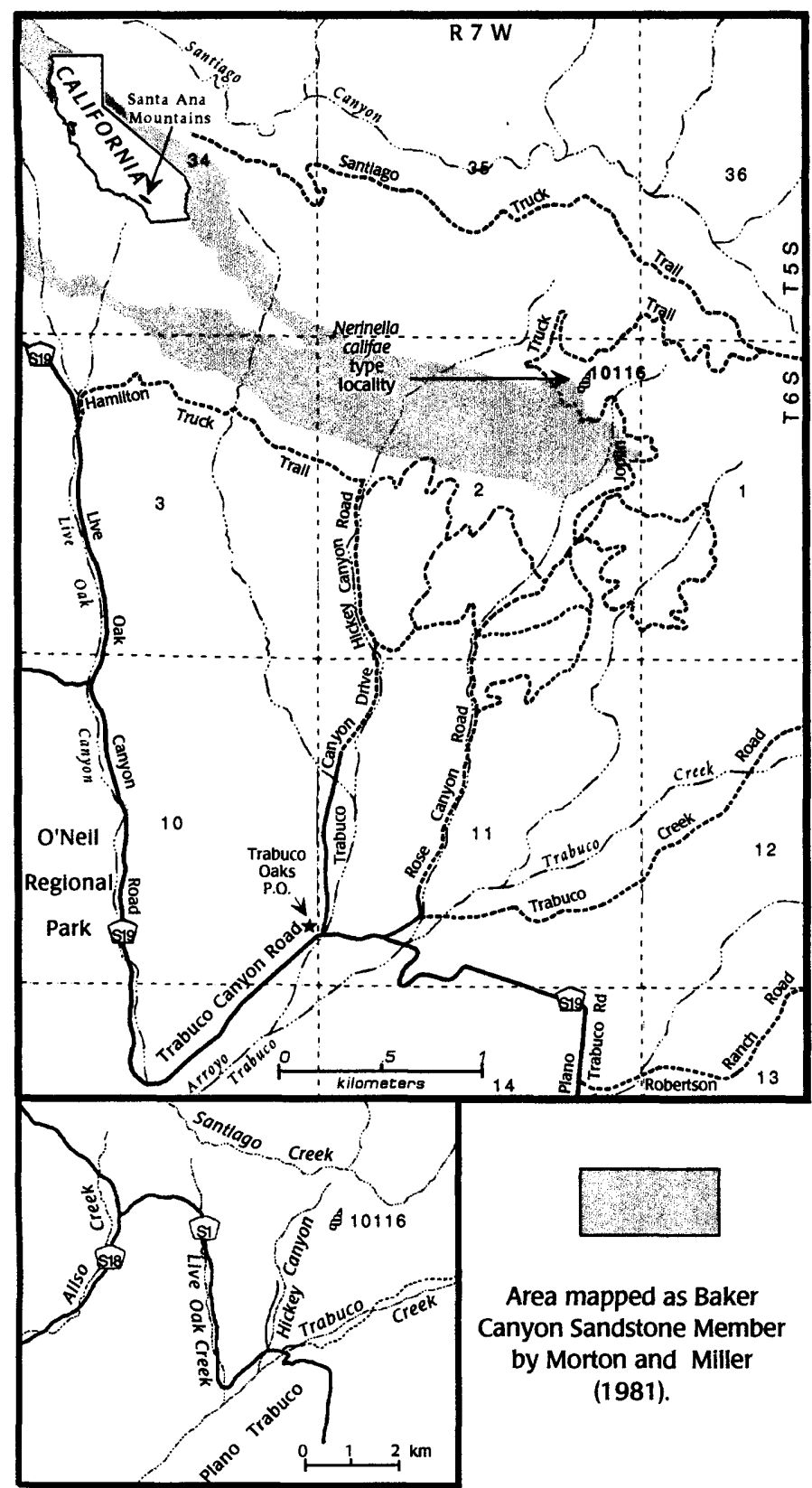

FIGURE 1 -Index map for area north of Plano Trabuco which has produced the only two species of nerineoids found in the Santa Ana Mountains. LACMIP loc. 10116 on ridge between Rose and Hickey Canyons. Names of roads and canyons variable on maps. On some maps road up Hickey Canyon labeled as "Trabuco Canyon Drive" is Trabuco Oaks Drive (Base from U.S.G.S. Santiago Peak Quadrangle, 1954).

\section{SYSTEMATIC PALEONTOLOGY}

Order Heterostropha Fischer, 1885

Superfamily NERINEOIDEA Zittel, 1873, n.t. Wenz, 1940

Family NerinELlidAE Pchelintsev, 1960

Genus NerinElla Sharpe, 1850

(=Nerinoides WENZ, 1940; non Nerinella NARDO, 1847 (ICZN OPINION $316,1954))$.

Type species.-Nerinea dupiniana d'Orbigny, 1843, by original designation; Early Cretaceous Hauterivian age, France.
Diagnosis.-Slender, acicular, multiwhorled nerineoids of moderately large length but small diameter, with concave whorl profile, protruding sutural ridges (suture between two spiral ribs), and granulate spiral costae. Interior with one palatal plait, one columellar plait, and weak or absent parietal plait. No umbilicus.

Discussion.-Nerinella is, in general, longer and more slender than Nerinea Defrance, 1825. The genus Nerinella is one of the earliest and longest ranging of nerineoids, appearing in earliest Jurassic (Hettangian) and ranging to Late Cretaceous (Maastrichtian according to Wenz, 1940; Senonian according to Pchelintsev, 1965). Korotkov (1997) listed it among genera becoming extinct in the Late Jurassic at the beginning of the Kimmeridgian, but as $N$. dupiniana is the type species, the genus was present in the Early Cretaceous. Species of Aptian age are listed by Wieczorek and Llompart (1997) from Spain.

Wenz (1940) provided the new name Nerinoides for Nerinella Sharpe, 1850 non Nardo, 1847, but Cox (1951) applied for an ICZN ruling to conserve Nerinella Sharpe, 1850 . Nerinella Sharpe, 1850 , was subsequently placed on the Official List of Generic Names in Zoology, and its type species Nerinea dupiniana d'Orbigny, 1843, was placed on the Offical List of Specific Names in Zoology (ICZN, 1954).

According to Kollmann (personal commun.), who has looked at d'Orbigny's types, the original figures of Nerinella dupiniana (d'Orbigny) are inadequate because they do not show a third internal fold (i.e., a parietal fold). The genus, none-the-less, has been considered to have two to three internal folds e.g., Pchelintsev (1965), Mongin (1990). Placement of those specimens that have only two folds into a separate, new genus should depend on more extensive material than is available in this present study.

Internally Nerinella califae is very similar to Costaella tricostata Kollmann (1976, p. 175, pl. 3, figs. 20-21) from the middle Albian to lower Cenomanian Losenstein Formation of northern Austria and Costaella kozanica Kollmann (1987, P. 44-45, pl. 2, fig. 28-30) from Cenomanian rocks of Greece. Kollmann (1976) indicated that a difference between Costaella Kollmann, 1976, and Nerinella was the strong costae of Costaella, and Nerinella califae differs externally in lacking the strong spiral sculpture of C. tricostata.

Three Pacific slope species were included in Nerinella by Saul and Squires (1998): Nerinella parallela (Anderson and Hanna, 1935) of Early Cretaceous, Aptian-Albian age from the Alicitos Formation of Baja California, Mexico; Nerinella santana Saul and Squires, 1998, of Late Cretaceous, Turonian age from the Baker Canyon Sandstone Member of the Ladd Formation in the Santa Ana Mountains, California; and Nerinella maudensis (Whiteaves, 1884) of probable Early Cretaceous, Albian age from the east end of Maude Island, Queen Charolotte Islands, British Columbia, Canada. Of these species, only $N$. parallela is associated with the coral-rudistid limestone facies in which nerineoids are most commonly found. In whorl profile, and strength and type of sculpture, the new species, here described as Nerinella califae, resembles illustrations of the type species $N$. dupiniana and of $N$. maudensis more than the more strongly ornamented species $N$. parallela and $N$. santana. Inspection of Whiteaves type specimens of $N$. maudensis makes possible new illustrations of this species (Fig. 2.7, 2.8) showing that the spiral sculpture is stronger than previously described.

\section{Nerinella CALIFAE new species} Figure 2.1-2.5

Diagnosis.-Thin shelled, acicular nerinellas having pleural angle of one to three degrees and high whorls with two nearly effaced barely noded spirals; whorl profile medially slightly concave, anteriorly barely convex. Two internal plaits with palatal 

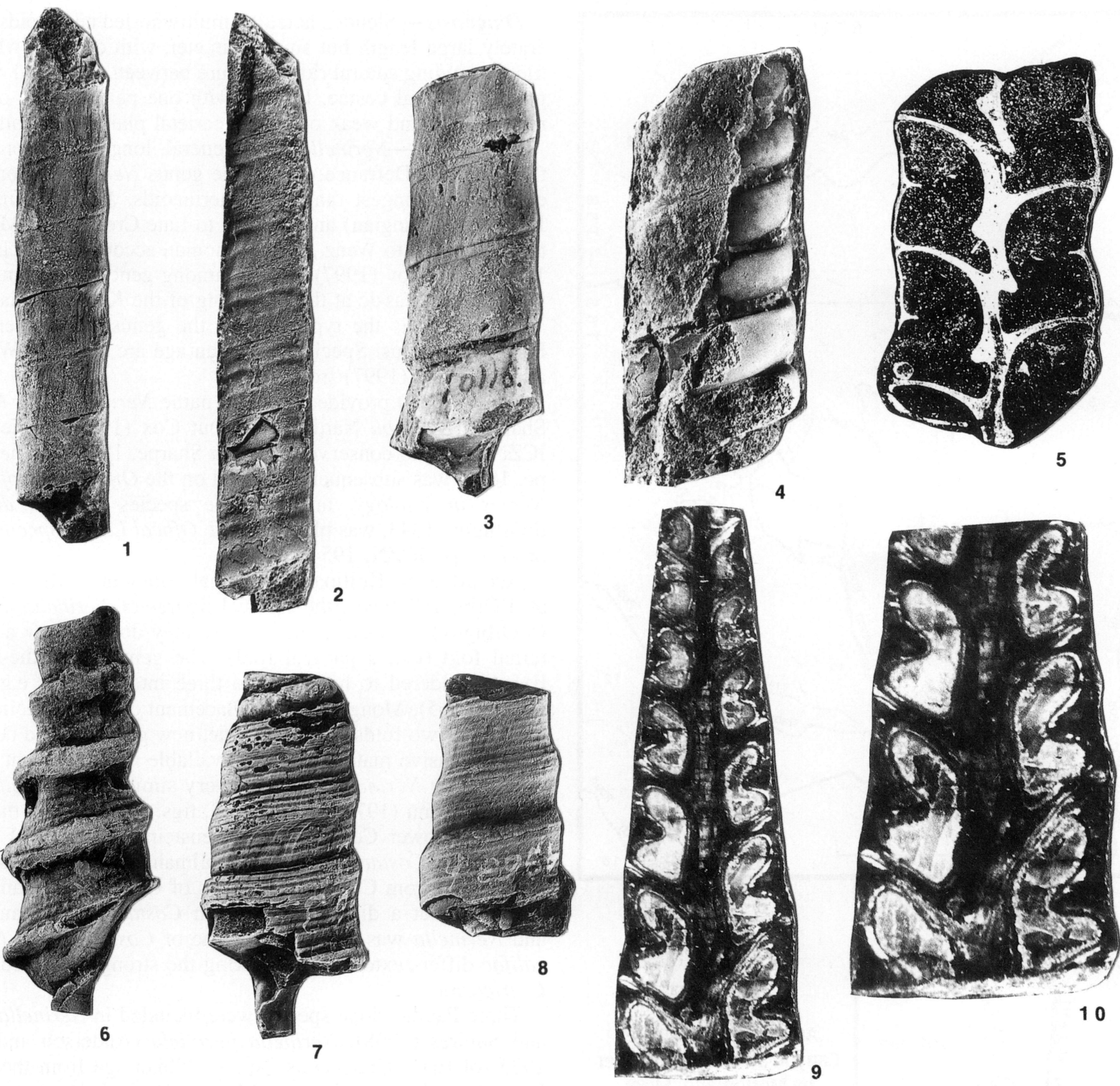

FIGURE 2-1-5, Nerinella califae n. sp., all from LACMIP loc. 10116, 1-4 coated with ammonium chloride; 1 , Holotype LACMIP 7305, $\times 1.3 ; 2-$ 5, paratypes; 2 , LACMIP $7306, \times 2.9 ; 3$, LACMIP 7307 , subsutural band, $\times 2 ; 4$, LACMIP 7308 , shell present on left side but missing on right side and showing steinkern with appearance of twice as many short whorls, $\times 4.6 ; 5$, LACMIP 7309 , section showing palatal and columellar plaits, $\times 2.6$, photo taken under low-angle lighting. 6-10, Nerinella maudensis (Whiteaves), all from east end Maude Island, Queen Charlotte Islands, $6-$ 8 coated with ammonium chloride; 6 , Holotype GSC 4963, $\times 1.4$, apparent "fold" on columella is break in shell; 7, syntype GSC 4963g, $\times 2.4$; 8, syntype GSC 4963h, ×2.6; 9-10, syntype GSC 4963c, section, 9, ×3.3; 10, ×4.8.

plait moderate at mid-whorl and columellar plait strong, anteriorly positioned.

Description.- Shell thin, multiwhorled, increasing very gradually in diameter. Pleural angle one to three degrees. Whorls relatively high, near two-thirds of diameter, early whorls (up to diameter of $5 \mathrm{~mm}$ ) nearly flat sided, later whorls concave, deepest medially. Protoconch unknown. Aperture unknown. Sculpture at diameter of about $5 \mathrm{~mm}$ of two faint, lightly noded spirals dividing whorl surface nearly into thirds, middle third slightly depressed, anterior third very slightly convex; sculpture fading on larger whorls. Subsutural band one $\mathrm{mm}$ high at whorl diameter of $10 \mathrm{~mm}$. Growth lines obscure, appearing opisthocline at subsutural band, steepening anteriorly. Interior with moderate palatal plait near mid whorl (strongest in early whorls), and columellar plait strong, anteriorly positioned.
Etymology.-The species is named for the mythical Amazonian Califa, after whom California is purported to have been named.

Types.-Holotype LACMIP 7305; paratypes LACMIP 73067309. All specimens from LACMIP 10116 (=CIT 1072) SW slope of Santa Ana Mountains, on spur near head of Rose Canyon, $213 \mathrm{~m}(700 \mathrm{ft}) \mathrm{S}, 323 \mathrm{~m}(1,060 \mathrm{ft}) \mathrm{W}$ of NE cor. sec. 2, T6S, R7W, Santiago Peak (7.5 minute) Quadrangle, Orange County, California. W. P. Popenoe collector, Nov. 26, 1932. Ladd Formation, Baker Canyon Sandstone Member.

Measurements.-Holotype LACMIP 7305 (seven whorls) 59 $\mathrm{mm}$ high, anterior-whorl diameter $11.2 \mathrm{~mm}$; posterior-whorl diameter 10.3; pleural angle near one degree. Paratype LACMIP 7307 (4 whorls) $31.4 \mathrm{~mm}$ high, anterior-whorl diameter $10.5 \mathrm{~mm}$, posterior-whorl diameter $9.2 \mathrm{~mm}$; paratype LACMIP 7308 (3 whorls) $12.5 \mathrm{~mm}$ high; paratype LACMIP 7306 (7+ whorls) 27 
$\mathrm{mm}$ high, anterior-whorl diameter $6.0 \mathrm{~mm}$; posterior-whorl diameter $4.0 \mathrm{~mm}$; pleural angle near five degrees; paratype LACMIP $730921.5 \mathrm{~mm}$ high.

Occurrence.-This species is known only from the type locality, which was described by Popenoe in the C.I.T. locality book as a boulder in a faulted zone just above the basement. The map of Morton and Miller (1981) shows a landslide in this area. The associated fossil bivalves Glycymeris pacificus Anderson, 1902; Lima beta Popenoe, 1937; Pachycardium coronaense (Packard, 1922); and Crassatella gamma Popenoe, 1937, as well as the gastropods Ampullina pseudalveata (Packard, 1922) and Trochactaeon (Trochactaeon) packardi (Anderson, 1958), suggest a late Turonian age. All of the specimens $(40+)$ of Nerinella califae are incomplete. Some specimens have been reassembled from fragments, and probably more fragments originally made up longer specimens but connecting segments have been lost, and an accurate count of number of individuals is not now possible. Certainly, the species was common or abundant at this locality.

Discussion.-The holotype and largest fragment of the new species is $59 \mathrm{~mm}$ high. It has a pleural angle near one degree; a rate of increase, which if maintained throughout, would result in a shell more than $60 \mathrm{~cm}$ high. However, the pleural angle of this species apparently decreases with maturity as the angle at diameters of less than $6 \mathrm{~mm}$ is near five degrees, and is three degrees at a diameter greater than $6 \mathrm{~mm}$. Estimated height for the holotype before being broken was perhaps near $40 \mathrm{~cm}$.

The medial placement of the palatal fold and its strength cause internal casts of $N$. califae to appear short whorled, as each whorl is divided so deeply by the palatal fold as to appear to be two whorls (Fig. 2.4). On some specimens the position of the palatal fold is marked on the whorl exterior by a slight groove.

The finely beaded spiral sculpture of $N$. califae is somewhat stronger on the earlier whorls and becomes almost effaced on the larger whorls. Nerinella parallela and $N$. santana have a straighter whorl profile and coarser sculpture than Nerinella califae. Original illustrations of $N$. maudensis (Whiteaves, 1884, pl. 27, fig. 2, 2a-2d) suggest more similarity to $N$. califae than examination of the actual specimens shows. Nerinella califae differs from $N$. maudensis in having a narrower pleural angle, weaker spiral sculpture, and relatively higher whorls. From the type species $N$. dupiniana, Nerinella califae differs in having a less concave whorl profile with a slight anterior convexity. Nerinella subaequalis (d'Orbigny, 1842) from the Turonian of France has a straighter whorl profile and wider pleural angle than $N$. califae.

\section{NeRINELla MAUDENSIS (Whiteaves, 1884)}

Figure 2.6-2.10

Nerinea Maudensis. Whiteaves, 1884, p. 214, pl. 27, fig. 2, 2a-2d; BoLTON, 1965, p. 55.

Types.-Syntypes GSC 4963, 4963a, 4963b, 4963c, 4963d, 4963e, 4963f, 4963g, 4963h, 4963i, from east end of Maud Island, opposite Leading Island, in Skidegate Inlet, Queen Charlotte Islands, British Columbia

Material examined-Syntypes GSC 4963, 4963a, 4963b, 4963c, 4963e, 4963g, 4963h.

Occurrence.-The species is based on material collected by $\mathrm{G}$. M. Dawson from the east end of Maud Island, opposite Leading Island, in Skidegate Inlet, from strata inferred by Bolton (1965) to be Haida Formation. No new occurrence of $N$. maudensis has been reported since Whiteaves' (1884) description. Saul and Squires (1998) indicated a possible Albian age. Additional information as to the age of the species is, at present, not available.
Discussion.-Technically Nerinella maudensis is a new combination, but actually Whiteaves ended his description of this species with the statement that it belongs to the subgenus Nerinella of Sharp. Whiteaves figured four specimens; Bolton (1965) found three of these and listed ten syntypes for the species. Through the kindness of B. J. Dougherty, Collection Manager, Geological Survey of Canada, seven of these specimens were loaned to the Natural History Museum of Los Angeles County. The photograph of GSC 4963 indicates that Whiteaves' figures 2, 2a were improvements on the original, but the new figure for GSC $4963 \mathrm{c}$ is very similar to Whiteaves' figure $2 \mathrm{~d}$. Syntypes $4963 \mathrm{~g}$ and $4963 \mathrm{~h}$ are illustrated because they show the sculpture and growth line more clearly than GSC 4963. They also show undeformed whorl profiles. Whiteaves (1884) described the sculpture as "fine and threadlike spiral raised lines", although his figure 2 a shows it as fine cords separated by fine lines. The whorl sides of GSC 4963 are broken and depressed giving them a more concave profile than less damaged specimens show, and the sculpture is difficult to see on this specimen. Sculpture appears to be somewhat variable and may weaken with maturity. The spirals are strongest on the anterior third of the whorl and weakest on the posterior third; on the middle, more concave part of the whorl the interspaces are most noticeable. Three spirals adapical to the suture are broadest with narrowest interspaces. The next three spirals are weaker, more distant, and more threadlike. Spirals abapical to the subsutural band are variable in number and strength, but are not strong. The growth line is very strongly opisthocline approaching the subsutural band. In the sectioned specimen (Whiteaves, fig. 2d; Fig. $2.9,2.10)$ a lighter area within the columella suggests the possibility of an umbilicus, but growth lines continue through it, and the material is very different from the crystaline calcite filling the whorls. Only the one palatal plait shows up strongly in this small specimen, but perhaps it does not provide an adult number of internal folds.

\section{ACKNOWLEDGMENTS}

We appreciate the assistance of L. T. Groves of Natural History Museum of Los Angeles County in finding references and providing access to the collections. We thank B. J. Dougherty and the Geological Survey of Canada for the loan of specimens from British Columbia. This note benefited from valuable comments by M. J. Barker of Portsmouth Polytechnic. Portsmouth, England and H. A. Kollmann, Natural History Museum of Vienna.

\section{REFERENCES}

Anderson, F. M. 1902. Cretaceous deposits of the Pacific Coast. California Academy of Sciences, Proceedings, Series 3, 2:1-154, pls. 112.

Anderson, F. M. 1958. Upper Cretaceous of the Pacific Coast. Geological Society of America, Memoir 71, 378 p., 75 pls.

ANDERSON, F. M., AND G. D. HANNA. 1935. Cretaceous geology of Lower California. California Academy of Sciences, Proceedings, Series 4, 23:1-34, pl. 1-11.

BARKER, M. J. 1990. The paleobiology of nerineacean gastropods. Historical Biology, 3:249-264.

Bolton, T. E. 1965. Catalogue of type invertebrate fossils of the Geological Survey of Canada. Volume II. Geological Survey of Canada, Ottawa, $344 \mathrm{p}$.

CONRAD, T. A. 1862. Descriptions of new genera, subgenera, and species of Tertiary and Recent shells. Academy of Natural Sciences of Philadelphia, Proceedings, 14:284-291.

Cox, L. R. 1951. Application for a ruling that the 'Prodomo' of S. A. Renier and the 'Prospetto della Classe dei Vermi' (dated 1804) prepared for inclusion in the 'Prodoma' were not published within the meaning of Article 25 of the 'Règles.' Bulletin of Zoological Nomenclature, 2:299-300.

Defrance, J. M. L. 1825. Article sur les Neriné, p. 462-464. In Dictionnaire des Sciences naturelles dans lequel on traite méthodiquement 
des differens Êtres de la Nature. .... Suppléments 34 bis 38: Strasbourg et Paris, 60 vols.

FISCHER, P. 1880-1887. Manuel de Conchyliologie et de Paléontologie Conchyliologique. F. Savy Librairie, Paris, 1369 p., 23 pl.

FRY, J. G., D. J. BOTTJER, AND S. P. LUND. 1985. Magnetostratigraphy of displaced Upper Cretaceous strata in southern California. Geology, 13:648-651.

INTERNATIONAL COMMISSION ON ZOOLOGICAL NOMENCLATURE. 1954. Opinion 316: Rejection for nomenclatorial purposes of the Tavola alfabetica delle Conchiglei Adriatiche and Prospetto della Classe di Ver$m i$ of S. A. Renier commonly attributed to the year 1804. Opinions and declarations rendered by the International Commission on Zoological Nomenclature, 9(5):91-100.

KollmanN, H. A. 1976. Gastropoden aus den Losensteiner Schichten der Umgebung von Losenstein (Oberösterriech). Annalen des Naturhistorischen Museums in Wien, 80:163-206, pl. 1-7.

Kollmann, H. A. 1987. Eine Cenomane Gastropodenfauna aus Nea Nikopolis bei Kozani (Mazedonien, Griechenland). Annalen des Naturhistorischen Museums in Wien, 89(A):37-56, pl. 1-3.

KorotKov, V. A. 1997. The Jurassic-Cretaceous phase in the evolution of nerineids (Gastropoda). Paleontological Journal, 31(6):595-599. [Translated from Paleontologicheskii Zhurnal, 1997, 6: 29-33].

Kowalke, V. T., AND K. BANDEL. 1996. Systematik und Päloökologie der nordalpinen Brandenberg-Gosau (Oberconiac/Untersanton) mit einem Vergleich zur Gastropodenfauna des Maastrichts des Trempbeckens (Südpyrenäen, Spanien). Mitteilungen der Bayerischen Staatssammlung für Paläontologie und Historische Geologie, 36:15-17, pl. 110.

MeEK, F. B. 1863. Remarks on the family Actaeonidae, with descriptions of some new genera and subgenera. American Journal of Science, Series 2, 35:84-94.

Mongin, D. 1990. Les mollusques Crétacés du gisement de bauxite de Bacque, Pyrenees Ariegeoises, France. Revue de Paléobiologie, 9(2): 321-334.

MORTON, P. K., AND R. V. Miller. 1973. Geologic map of Orange County, California. In P. K. Morton, R. V. Miller, and D. L. Fife (compilers), Preliminary Geo-Environmental Maps of Orange County, California. California Division of Mines and Geology, Preliminary Report 15.

MORTON, P. K., AND R. V. Miller. 1981. Geologic map of Orange County California showing mines and mineral deposits. California Division of Mines and Geology, Bulletin 204, plate 1 (later designated Miscellaneous Publications MM007. Also accompanies P. K. Morton et al., 1979, Environmental Geology of Orange County. California Division of Mines and Geology, Open-File Report 79-08).

NARDo, G. D. 1847. Prospetto della fauna marina volgare del Veneto estuario, p. 113-156. In Venezia e le sue Lagune, Volume 2, Pt. 1. Antonelli, Venice.

OrbignY, A. D'. 1842-1843. Paléontologie Française, Terrains Crétacés volume 2, Gastéropodes. Published by the author, Paris, 465 p., pl. 149-236, 153bis, 186 bis.

PACKARD, E. L. 1922. New species from the Cretaceous of the Santa Ana Mountains, California. University of California Publications, Department of Geological Sciences, Bulletin, 31:413-462, pl. 24-38.

PCHELINTSEV, V. F. 1960. Superfamily Nerineacea, p. 119-125. In V. F. Pchelintsev and I. A. Korobkov (eds.), Mollyuski-Bryukhonogie, Osnovy Paleontologii. Gosudarstvennoe nauchno-tekhnicheskoe izdatel'stvo literatury po geologii i okhrane nedr. Mockha, 4.

PCHELINTSEV, V. F. 1965 [1968]. Mesozoic Murchisoniata of the Crimean highlands. American Geological Institute, International Geology Review, Book Section iv +46 p, 8 pls. [Partial translation of Mesozoic Murchonisoniata from the strata of the Crimean mountains. Izvestiya Akadmii Nauk SSSR, Moscow-Leningrad].

PONDER, W. F., AND A. WARÉN. 1988. Classification of the Caenogastropoda and Heterostropha-a list of the family-group names and higher taxa. Malacological Review, Supplement 4, Appendix: 288-328.

POPENOE, W. P. 1937. Upper Cretaceous Mollusca from southern California. Journal of Paleontology, 11:379-402, pl. 45-49.

SAUL, L. R., AND R. L. SQuires. 1998. New Cretaceous Gastropoda from California. Palaeontology, 41:461-488, 3 pls.

SHARP, D. 1850. Remarks on the genus Nerinaea, with an account of the species found in Portugal. Quarterly Journal of the Geological Society, London, 6:101-115, pl. 12-13.

SoHL, N. D. 1987. Cretaceous gastropods: contrasts between Tethys and the temperate provinces. Journal of Paleontology 61:1085-1111.

SoHL, N. D., AND H. A. KollmanN. 1985. Cretaceous actaeonellid gastropods from the Western Hemisphere. United States Geological Survey Professional Paper 1304, 104 p.

TAYlOR, J. D., N. J. Morris, AND C. N. TAYlOR. 1980. Food specialization and the evolution of predatory prosobranch gastropods. Palaeontology, 23:375-409.

WENZ, W. 1940. Superfamilia Nerineacea, p. 816-831. In O. H. Schindewolf (ed.), Handbuch der Paläozoologie, Band 6, Prosobranchia, Teil 4. Gebrüder Borntraeger, Berlin [Reprinted 1960-1961].

Whiteaves, J. E. 1884. On the fossils of the coal-bearing deposits of the Queen Charlotte Islands, British Columbia. Geological Survey of Canada, Mesozoic Fossils, 1(3):191-262, pl. 21-32.

WiECZOREK, J., AND C. LlOMPART. 1997. Cretaceous nerineacean gastropods in Spain: stratigraphic and biogeographic remarks. Batalleria, $7: 5-8$.

ZiTTEL, K. A. 1873. Gastropoden der Stramberger Schichten. Palaeontographica: Beiträge zur Naturgeschichte der Vorwelt, Supplement Band 2, 3:193-373.

ACCEPTED 10 APRIL 2001 